\title{
Chitosan/Siloxane Hybrid Polymer: Synthesis, Characterization and Performance as a Support for Immobilizing Enzyme
}

\author{
Grazielle S. Silva, Pedro C. Oliveira, Domingos S. Giordani and Heizir F. de Castro*
}

Escola de Engenharia de Lorena, Universidade de São Paulo, CP116, 12602-810 Lorena-SP, Brazil

\begin{abstract}
O polímero híbrido derivado de siloxano e quitosana foi obtido pela técnica sol-gel, tendo como precursor o tetraetilortosilicato (TEOS). O suporte híbrido obtido foi modificado quimicamente com epicloridrina e utilizado para imobilizar lipase de Burkholderia cepacia. O híbrido $\mathrm{SiO}_{2}$-quitosana deu origem a uma nova estrutura macromolecular na qual as partículas inorgânicas encontramse dispersas em escala nanométrica na matriz orgânica e ligadas à matriz por meio de ligações covalentes. Foi realizado um estudo comparativo entre a lipase livre e a imobilizada quanto à influencia do $\mathrm{pH}$ e temperatura, parâmetros cinéticos e estabilidade térmica. $\mathrm{O} \mathrm{pH}$ ótimo para a atividade máxima de hidrólise da lipase imobilizada foi de 6,1 , enquanto que para a lipase livre foi de 7,0. A temperatura ótima permaneceu em $50^{\circ} \mathrm{C}$ mesmo depois da imobilização. Os perfis de estabilidade térmica indicaram que o processo de imobilização foi favorável à estabilização da enzima e o derivado epóxi $\mathrm{SiO}_{2}$-quitosana foi cerca de 30 vezes mais estável que a lipase livre a $60{ }^{\circ} \mathrm{C}$.
\end{abstract}

A hybrid polymer derived from siloxane and chitosan was obtained by sol-gel technique using tetraethoxysilane (TEOS) as a precursor. The hybrid support was chemically modified with epichlorohydrin and used to immobilize lipase from Burkholderia cepacia. The hybrid $\mathrm{SiO}_{2}$-chitosan formed new macromolecular structure in which the inorganic particles are dispersed at the nanometer scale in the organic host matrix and bounding through covalent bonds. A comparative study between free and immobilized lipase was provided in terms of $\mathrm{pH}$, temperature, kinetic parameters and thermal stability. The $\mathrm{pH}$ for maximum hydrolysis activity shifted from 7.0 for the soluble lipase to 6.1 and the optimum temperature remained at $50{ }^{\circ} \mathrm{C}$ after immobilization. The patterns of heat stability indicated that the immobilization process provided the stabilization of the enzyme and the epoxy $\mathrm{SiO}_{2}$-chitosan derivative was almost 30 -fold more stable than soluble lipase at $60^{\circ} \mathrm{C}$.

Keywords: chitosan, hybrid matrix, lipase, immobilization

\section{Introduction}

Enzyme immobilization usually provides, in addition to the desired reuse of the biocatalyst, unexcelled advantages such as product separation and continuous operation. ${ }^{1}$ Moreover, immobilization may be used to improve other enzyme features, such as increasing the activity, ${ }^{2}$ decreasing inhibitions, ${ }^{3}$ modulating selectivity and specificity ${ }^{4}$ or improving the enzyme behavior in synthetic processes. ${ }^{5}$ Particularly for lipase,${ }^{6}$ the immobilization state is required to attain high product yield so it is not surprise that its immobilization has been the object of intensive investigation. ${ }^{6}$ Several commercially immobilized preparations are available,

*e-mail: heizir@dequi.eel.usp.br such as Candida antarctica lipase B immobilized onto polyacrylate type matrix, available under the name of Novozym $435^{\circledR}$ (Novozymes) or Chirazyme L-2 ${ }^{\circledR}$ (Roche). Some lipases are also available in the cross-linked forms, such as cross-linked enzyme crystals (CLECs) offered by Altus Biologics Inc. However, for some applications, the relatively high cost of those biocatalysts associated with the usage of an expensive carrier material, becomes unfeasible for further exploitation. Therefore, the development on less expensive immobilizing procedure is need to emerge into relative low margin applications such as interesterification of fats when compared to the relative high margin applications, for example enantioselective synthesis of pharmaceutical intermediates. ${ }^{6}$

The organic-inorganic sol-gels have received significant interest because the incorporation of organic polymers in 
the inorganic sol-gel can lead to new composite materials possessing the properties of each component that would be useful in particular applications. ${ }^{7}$ This method has been considered as outstanding to synthesize a significant number of materials with high degree of homogeneity and purity at a molecular level with extraordinary physical and chemical properties. ${ }^{8}$ The sol-gel reaction involves the hydrolysis of silica precursors and condensation of the resulting hydroxyl groups to form a nano-structure. It has been widely used in the fields of mesoporous materials, membrane materials and intelligent hybrid hydrogel. ${ }^{9-12}$ One simple method is mixing organic compounds with a metal alkoxide, such as tetraethoxysilane (TEOS).

It has been reported that the inorganic nanocomposite is formed in situ in a biopolymer solution by the selforganization of sol particles generated in the course of hydrolysis of TEOS and following polycondensation reactions into a porous three-dimensional network in the bulk solution. During the sol-gel process the inorganic mineral is deposited in the organic compound matrix forming hydrogen bonding between organic and inorganic phases. To increase the solubility, methanol or ethanol is usually added. ${ }^{13}$ Some organic/inorganic hybrids on the basis of different inorganic precursors and organic compounds, such as cellulose, ${ }^{12}$ carrageenan ${ }^{13}$ and polyvinylalcohol ${ }^{14}$ have been reported. Incorporation of organic polymers, especially those with amino or amide groups, allows the formation of molecular hybrids often stabilized by strong hydrogen bonding..$^{15}$ Moreover, chemical additives can be used to improve the process and the attainment of materials with better mechanical properties, porosity control and hydrophilic/hydrophobic balance. ${ }^{16}$

Several applications have been already developed for this kind of hybrid materials particularly in the biotechnological field. The dispersed inorganic particles impart the properties of hardness, brittleness and transparency, whereas density, free volume and thermal stability depend on the organic host polymer. ${ }^{17-19}$ Hydrolysis and condensation reactions are basically responsible for polymerization of the inorganic precursors.

Using this methodology, polymers such as chitosan are able to form hybrids with silica. ${ }^{15}$ This macromolecule, derived chemically by deacetylation of chitin, the second most abundant biopolymer in nature close to cellulose, has widely been assumed to be a cheaper and versatile sorbent for transition metal ions and organic substances through the coordination and/or reaction sites composed of the amino $\left(-\mathrm{NH}_{2}\right)$ and hydroxy $(-\mathrm{OH})$ groups anchoring on chitosan chains. ${ }^{20}$ As a matter of fact silica-chitosan possesses a highly porous microstructure and has been shown to be a superior support for immobilizing enzymes. ${ }^{1}$ Moreover, it is inexpensive, non-toxic, hydrophilic, biocompatible and biodegradable. ${ }^{21}$

Thus, this work assesses the performance of a silicachitosan hybrid matrix synthesized by sol-gel process, using TEOS as a precursor to immobilize lipase from Burkholderia cepacia. This enzyme was chosen due to its potential previously identified to synthesize important products, such as biodiesel and monoglycerides. ${ }^{22-23}$ The properties of the support $\left(\mathrm{SiO}_{2}\right.$-chitosan) and immobilized derivative were evaluated by X-ray diffraction, Fourier transform infrared spectroscopy (FTIR) and termogravimetry (TG). The influence of the temperature and $\mathrm{pH}$ on the activity of the biocatalysts was determined using a surface response methodology. Under the established conditions, the kinetic behavior of the immobilized lipase was also determined. The results were compared with those attained by the free lipase.

\section{Experimental}

\section{Materials}

Burkholderia cepacia (Lipase PS) was purchased from Amano Enzyme Inc. (Nagoya, Japan) and used without further purification. Chitosan flaks (C3646-Sigma) with a degree of deacetylation of $85 \%$ and tetraethoxysilane (TEOS) were obtained from Sigma-Aldrich Chemicals Co. (Milwaukee, WI, USA). Epichlorohydrin, hydrochloric acid (minimum 36\%) and polyethylene glycol (PEG, molecular weight-1500) were supplied by Reagen (Rio de Janeiro, RJ, Brazil). Commercial olive oil (low acidity) was purchased in a local market. All other chemicals were of analytical grade.

\section{Support synthesis and activation}

$\mathrm{SiO}_{2}$-chitosan was prepared by the hydrolysis and polycondensation of tetraethoxysilane according to the methodology reported by Paula et al. ${ }^{16}$ with slight modifications as briefly described. An initial solution of chitosan $(0.125 \mathrm{~g})$ and ethanol $(5 \mathrm{~mL})$ in water $(20 \mathrm{~mL})$ was heated at $60^{\circ} \mathrm{C}$ under agitation, followed by addition of $1.0 \mathrm{~mL}$ of concentrated $\mathrm{HCl}$. The solution was stirred for $12 \mathrm{~h}$ for total chitosan dissolution. After this period, $5 \mathrm{~mL}$ of TEOS were added under agitation for $40 \mathrm{~min}$ and the product was transferred to micro wells of tissue culture plates (disc shape) and kept at $25{ }^{\circ} \mathrm{C}$ until complete gel solidification (formation of an interpenetrated network of $\mathrm{SiO}_{2}$-chitosan). Then, the material was ground in a ball mill and classified to attain particles with $0.308 \mathrm{~mm}$ of diameter (-40/+60 MESH Tyler standard sieves). Activation of the 
hybrid particles was carried out with epichlorohydrin at $2.5 \%(\mathrm{~m} / \mathrm{v})$ and $\mathrm{pH} 7.0$ for $1 \mathrm{~h}$ at room temperature, followed by exhaustive washings with distilled water.

\section{Lipase immobilization onto epoxy $\mathrm{SiO}_{2}$-chitosan particles}

Activated epoxy $\mathrm{SiO}_{2}$-chitosan particles were soaked into hexane under stirring $(100 \mathrm{rpm})$ for $1 \mathrm{~h}$ at $25^{\circ} \mathrm{C}$. Then, excess hexane was removed and powder lipase preparation was added at a ratio of 1:4 $\mathrm{g}$ of enzyme per $\mathrm{g}$ of support. PEG-1500 as lipase stabilizer was added together with the enzyme at a fixed amount ( $5 \mathrm{mg} \mathrm{g}^{-1}$ of support). Lipase-support system was maintained in contact for $16 \mathrm{~h}$ at $4{ }^{\circ} \mathrm{C}$ under static conditions. The immobilized lipase derivatives were filtered (nylon membrane 62HD from Scheiz Seidengazefabrik AG, Thal Schweiz, Switzerland) and thoroughly rinsed with hexane. Hydrolytic activities of free and immobilized lipase derivatives were assayed by the olive oil emulsion method according to the modification proposed by Soares et al. ${ }^{24}$ One unit (U) of enzyme activity was defined as the amount of enzyme that liberates $1 \mu \mathrm{mol}$ of free fatty acid per min under the assay conditions. The results were expressed in activity units per $\mathrm{g}$ of solid (free enzyme preparation or immobilized derivative).

\section{Determination of optimal enzymatic activities and kinetic parameters}

Enzymatic activities for free and immobilized lipases as a function of temperature and $\mathrm{pH}$ were investigated according to a five-level-two-factor central composite rotatable design (CCRD) with three replications at the center point. The activities were assayed by the hydrolysis of olive oil emulsion at a fixed proportion oil/water 1:1.24 The $\mathrm{pH}$ values were achieved using appropriate phosphate buffer solutions $\left(0.1 \mathrm{~mol} \mathrm{~L}^{-1}\right)$. Results from the experimental design were analyzed using Statistica version 5 (StatSoft Inc., USA). The statistical significance of the regression coefficients was determined by Student's test; the second order model equation was determined by Fischer's test and the proportion of variance explained by the model obtained was given by the multiple coefficient of determination, $\mathrm{R}^{2}$.

The influence of substrate concentration on the hydrolytic activities was also analyzed in the olive oil hydrolysis assay varying the proportion of oil in the emulsion from 10 to 50\%. Michaelis-Menten constant $\left(\mathrm{K}_{\mathrm{m}}\right)$ as the concentration of substrate at which half of the maximum reaction rate $\left(\mathrm{V}_{\text {max }}\right)$ is reached was calculated with aided by computational program Enzfitter version 1.05 published by Elsevier-Biosoft, 1987. In all cases, enzyme activity was measured as the initial reaction rate $(0-5 \%$ hydrolysis) to avoid the possible inhibition that might take place due to the appearance of reaction products.

\section{Thermal stability}

Soluble $(1.0 \mathrm{~mL})$ and immobilized derivative $(0.1 \mathrm{~g})$ were incubated in the presence of $1 \mathrm{~mL}$ buffer phosphate $\mathrm{pH} 6.5\left(100 \mathrm{mmol} \mathrm{L}^{-1}\right)$ at $60^{\circ} \mathrm{C}$ for different time intervals. Samples were removed and assayed for residual activity as previously described, ${ }^{24}$ taking an unheated control to be $100 \%$ active. The rate of denaturation $\left(\mathrm{k}_{\mathrm{d}}\right)$ and half-life time $\left(\mathrm{t}_{1 / 2}\right)$ were calculated by equations 1 and 2 , respectively.

$\mathrm{A}_{\text {in }}=\mathrm{A}_{\text {ino }} \exp \left(-\mathrm{k}_{\mathrm{d}} \mathrm{t}\right)$

$\mathrm{t}_{1 / 2}=\ln 0.5 /-\mathrm{k}_{\mathrm{d}}$

\section{Characterization}

Fourier transform infrared spectroscopy (FT-IR, Perkin-Elmer, model spectrum GX FT-IR system) was used for studying chemical bonds between hybrid support and lipase. Micrographs were obtained with a scanning electron microscopy (SEM, LEO1450VP, Schott Zeiss from Brazil). X-ray diffraction patterns were collected on a XRD 6000 X-ray difractometer Shimadzu (Shimadzu from Brazil), using $\mathrm{CuK}$ radiation source, with $2 \theta$ angle varying from $15-80^{\circ}$. Thermal stability and weight loss profiles were determined using a thermo gravimetric analysisTG apparatus (TGA-50 Shimadzu-thermogravimetric analyzer). All TGA measurements were accomplished in nitrogen atmosphere and examined over the range of 25 to $1000{ }^{\circ} \mathrm{C}$, with a heating rate of $10^{\circ} \mathrm{C} \mathrm{min}{ }^{-1}$. The typical sample amount was $10.00 \pm 0.5 \mathrm{mg}$.

\section{Results and Discussion}

\section{Synthesis and characterization of $\mathrm{SiO}_{2}$-chitosan matrix}

Figure 1 is a hypothetic representation of the synthetic route used for the preparation of hybrid polymer by sol-gel process, involving three steps: ${ }^{25}$ (i) hydrolysis of the precursor $\left(\mathrm{SiO}_{2}\right)$ in acidic solution; (ii) polycondensation of the formed monomers to produce oligomers arranged as sol particles and (iii) formation of $\mathrm{SiO}_{2}$-chitosan hybrid matrix by cross-linking of the sol particles leading to a sol-gel transition.

The product of the polycondensation reaction is a typical inorganic glass type material having hydroxyl groups on the surface. The chitosan is adsorbed on silica particle via hydrogen bonds between sylanol groups in 
step 1 - hydrolysis

$\mathrm{nSi}\left(\mathrm{OC}_{2} \mathrm{H}_{5}\right)_{4}+\mathrm{H}_{2} \mathrm{O} \stackrel{\mathrm{H}^{+}}{\longrightarrow} \mathrm{nSi}\left(\mathrm{OC}_{2} \mathrm{H}_{5}\right)_{3} \mathrm{OH}+\mathrm{C}_{2} \mathrm{H}_{5} \mathrm{OH}$

step 2 - polycondensation

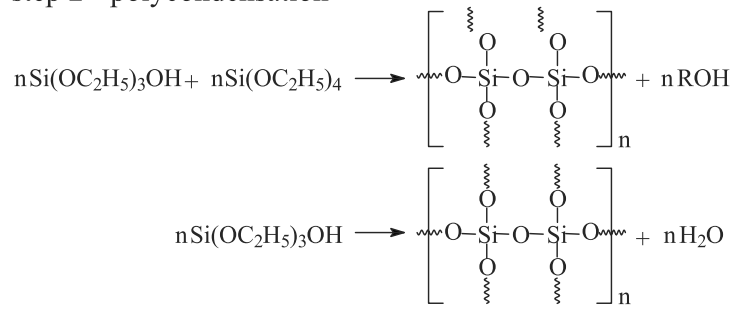

step 3 - matrix formation
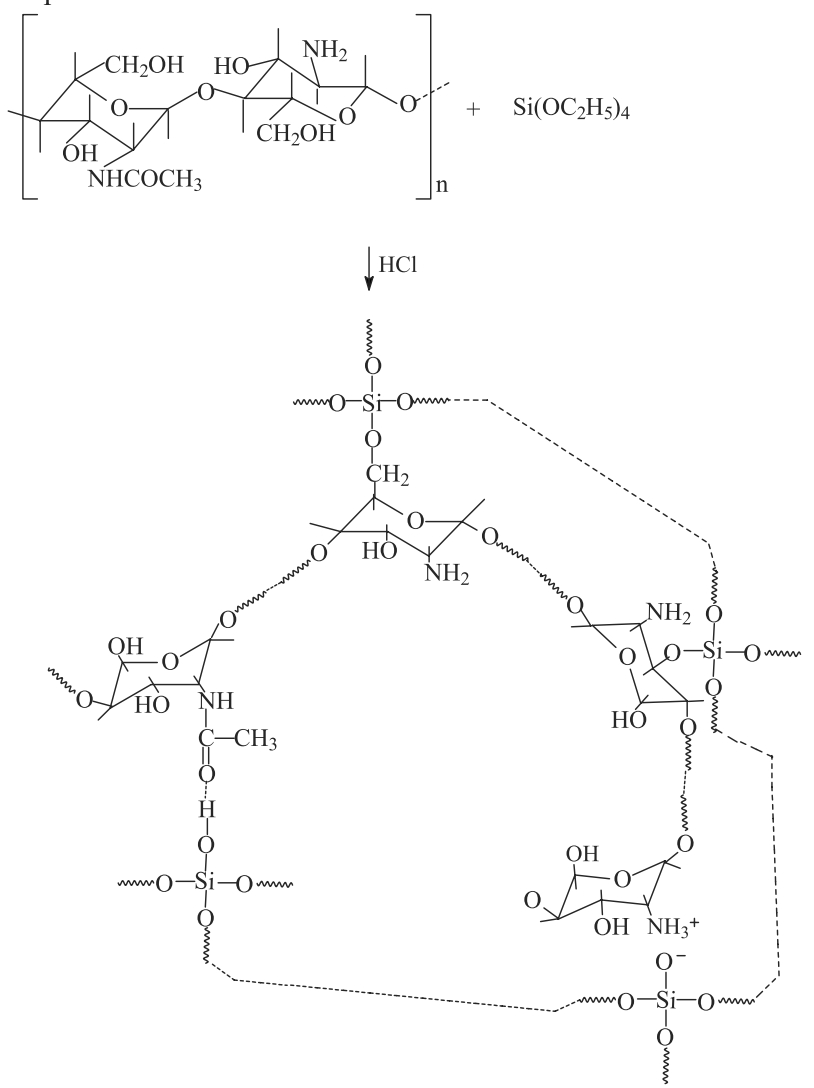

Figure 1. Hypothetic representation of $\mathrm{SiO}_{2}$-chitosan matrix formation (Adapted from reference 25).

the silica network and amide and oxy-groups of chitosan, ionic bounds between chitosan amino groups and sylanol groups as well as covalent bonds in result of esterification of chitosan hydroxyl-groups of sylanol groups of silica net work. ${ }^{25,26}$ The $\mathrm{SiO}_{2}$-chitosan hybrid forms new molecular structures containing not only organic groups, but also inorganic nano-silica particles. These inorganic particles are dispersed in the chitosan matrix, forming network organic-inorganic hybrid. $\mathrm{SiO}_{2}$-chitosan is transparent, vitreous, brittle and homogeneous (Figure 2).

The infrared spectrum (Figure 3 ) shows bands at 1110 to $1000 \mathrm{~cm}^{-1}$ corresponding to $\mathrm{Si}-\mathrm{O}-\mathrm{R}$ asymmetric stretching and hydroxyl groups $\left(3600-3200 \mathrm{~cm}^{-1}\right) .{ }^{27}$ Other characteristic bands were observed at $950 \mathrm{~cm}^{-1}(\mathrm{Si}-\mathrm{O}-\mathrm{Si}$ axial deformation), $810 \mathrm{~cm}^{-1}$ ( $\mathrm{Si}-\mathrm{O}-\mathrm{Si}$ axial deformation) and $600 \mathrm{~cm}^{-1}$ (Si-O-Si angular deformation). ${ }^{28}$

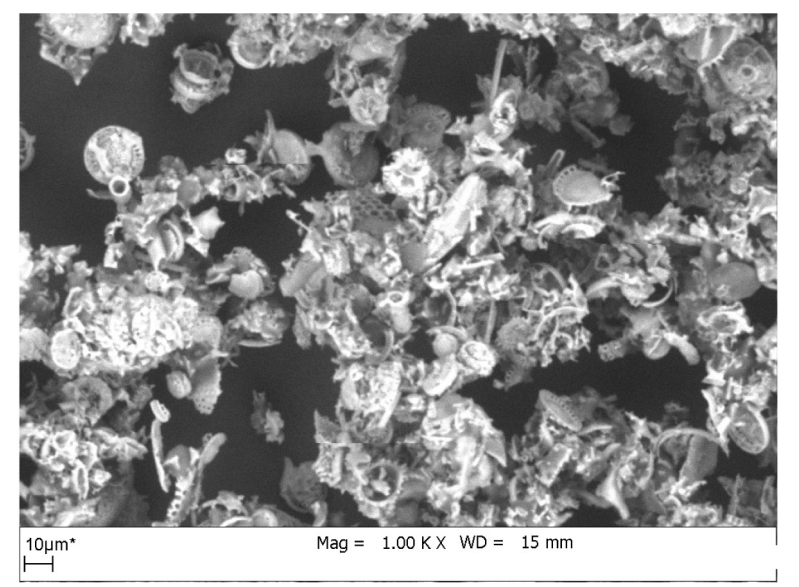

Figure 2. SEM micrograph for $\mathrm{SiO}_{2}$-chitosan.

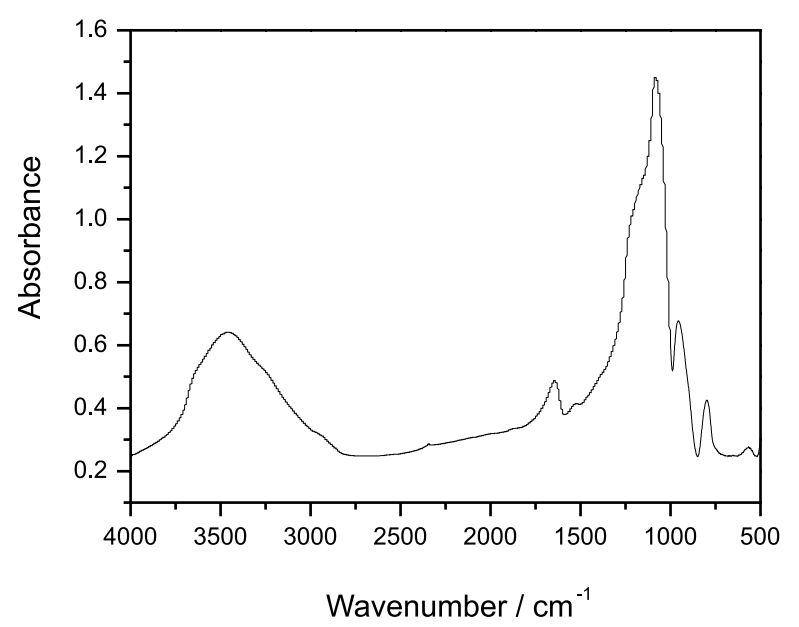

Figure 3. FTIR spectra for the $\mathrm{SiO}_{2}$-chitosan.

The XRD displays peaks of low intensity and expressive width, indicating a predominantly amorphous structure of the hybrid composite (Figure 4), with one halo centered around $23^{\circ}(2 \theta)$. According to Ogawa et al. ${ }^{29}$ pure chitosan could be arranged in noncrystalline, hydrated crystalline and anhydrous crystalline forms which is represented by peaks around $11.7^{\circ}, 14.2^{\circ}$ and $23^{\circ}$, respectively. The disappearance of these two cristalline peaks in hybrid composite indicates the prominence of chitosan amorphous structure, influencing directly the structure of hybrid composite.

$\mathrm{SiO}_{2}$-chitosan thermal behavior was evaluated by TGA as can be seen in Figure 5. The initial weight loss (26\%) was observed around $155^{\circ} \mathrm{C}$ and can be attributed to loss of adsorbed water on the surface of chitosan and side 
product of subsequent condensation of $\mathrm{Si}-\mathrm{OH}$ groups. ${ }^{27}$ The second weight loss (29\%) was observed at $275{ }^{\circ} \mathrm{C}$ due to the decomposition of low molecular weight species. Thermal decomposition was marked in the region of $275^{\circ} \mathrm{C}$ up to $800{ }^{\circ} \mathrm{C}$ (around $40 \%$ ). In this range of temperature probably occurred the dehydration of the saccharide rings, depolymerization and decomposition of the units of the organic polymer as well as the inorganic part of the hybrid. ${ }^{30,27}$ The higher temperature values for the first stage of decomposition observed for support compared to the first stage decomposition temperature of the pure chitosan $\left(60{ }^{\circ} \mathrm{C}\right),{ }^{31}$ indicates that the formation of the hybrid of $\mathrm{SiO}_{2}$-chitosan was successful.

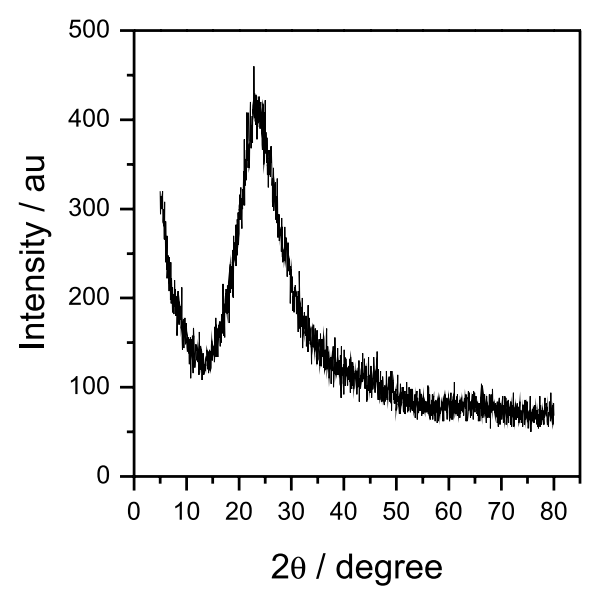

Figure 4. X-ray diffractogram for $\mathrm{SiO}_{2}$-chitosan.

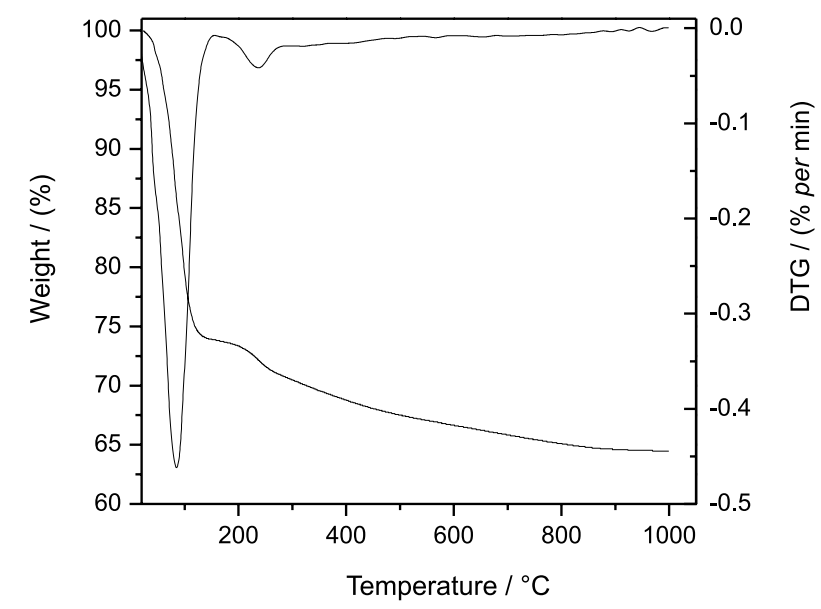

Figure 5. Thermal analysis for $\mathrm{SiO}_{2}$-chitosan.

\section{Morphological characteristics of the immobilized derivative}

$\mathrm{SiO}_{2}$-chitosan was submitted to activation procedure involved the incorporation of aldehyde groups on the surface of the support by reacting with the hydroxyls of $\mathrm{SiO}_{2}$-chitosan, aiming to render adequate functional groups to the covalent binding with the enzyme.
Epichlorohydrin reacts directly with the hydroxyl groups of chitosan generating epoxide groups which are able to link to the enzyme. Some reticulations can also be present, but it will depend on the degree of deacetylation of chitosan as well as concentration of activating agent and reaction time (Figure 6). ${ }^{32-34}$ PEG1500 (not shown) was used for improving activity of the biocatalyst as previous described. ${ }^{35}$

The epoxy $\mathrm{SiO}_{2}$-chitosan support was used to immobilize Burkholderia cepacia (lipase PS) by covalent binding. Typically $0.25 \mathrm{~g}$ of powder lipase per $\mathrm{g}$ of dry support was found to be sufficient to attain satisfactory retention of enzyme on the support $(30 \pm 0.5 \%)$ and immobilized derivative having high activity (1620 \pm 58 units $\mathrm{g}^{-1}$ support).

The efficiency of the methodology in relation to the lipase incorporation on the support was also assessed by infrared spectroscopy. This technique is used to detect the presence of covalent bonds in molecules, based on the principle that each type of covalent bond has a characteristic absorption wavelength represent as an upward peak on a charted spectrum. ${ }^{28}$ Figure 7 shows spectra for both free and immobilized lipase.

Free enzyme displayed a typical spectrum of proteins with bands associated to their characteristic amide group (CONH). In this case, in the range from 1700 to $1600 \mathrm{~cm}^{-1}$, there is a amide I band due to the double bond $\mathrm{CO}$ stretching, the $\mathrm{CN}$ stretching and $\mathrm{NH}$ bending. ${ }^{28}$

For the immobilized derivative, a slight additional bands in the spectrum at $1600 \mathrm{~cm}^{-1}$ was observed, indicating that the covalent bond between the enzyme and support occurred (NH bending). Bands corresponding to carboxyl deformation (2800 and $1500 \mathrm{~cm}^{-1}$ ) disappeared, which demonstrated that the characteristic functional groups of the lipase were covalently bond on the groups inserted in the support. ${ }^{28}$

Diffraction of the X-ray information data on the activated support (epoxy $\mathrm{SiO}_{2}$-chitosan) and immobilized derivative is shown in Figure 8. The diffractogram obtained from the epoxy $\mathrm{SiO}_{2}$-chitosan shows peaks of low intensity and expressive width, indicating a predominantly amorphous structure of the hybrid composite. ${ }^{14}$ The immobilization procedure resulted on support structure modifications which clearly indicated insertion of crystalline regions into the $\mathrm{SiO}_{2}$-chitosan that can be associated with the presence of the enzyme. As can be seen in the inserted box in Figure 8, free lipase exhibits XRD with peaks intense and narrow which is typical for high crystalline structure of protein. The insertion of this crystalline structure of the lipase on the immobilized derivative confirmed that the immobilization procedure was successfully achieved. 


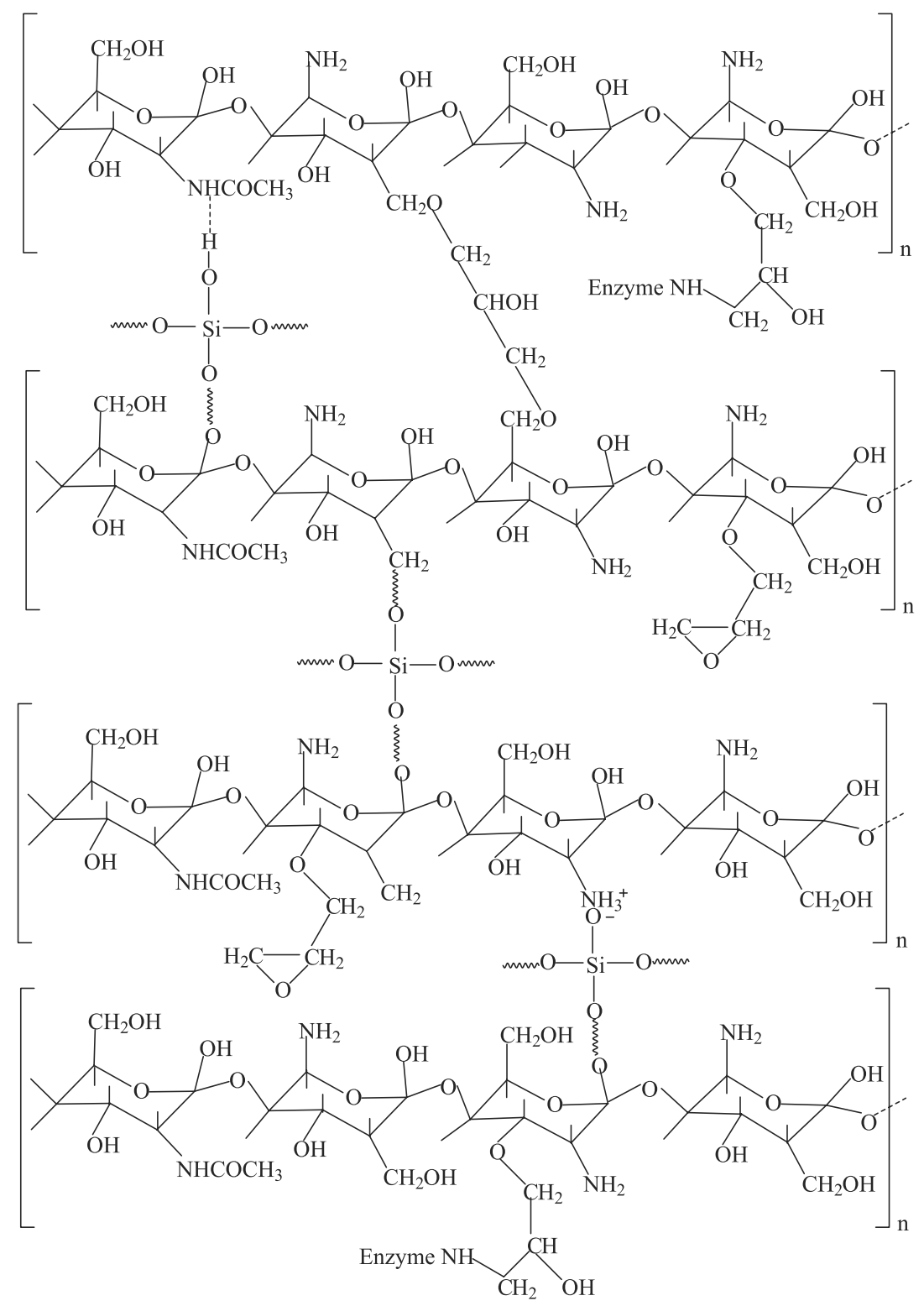

Figure 6. Proposed mechanism for $\mathrm{SiO}_{2}$-chitosan activation with epichlorohydrin and immobilization step.

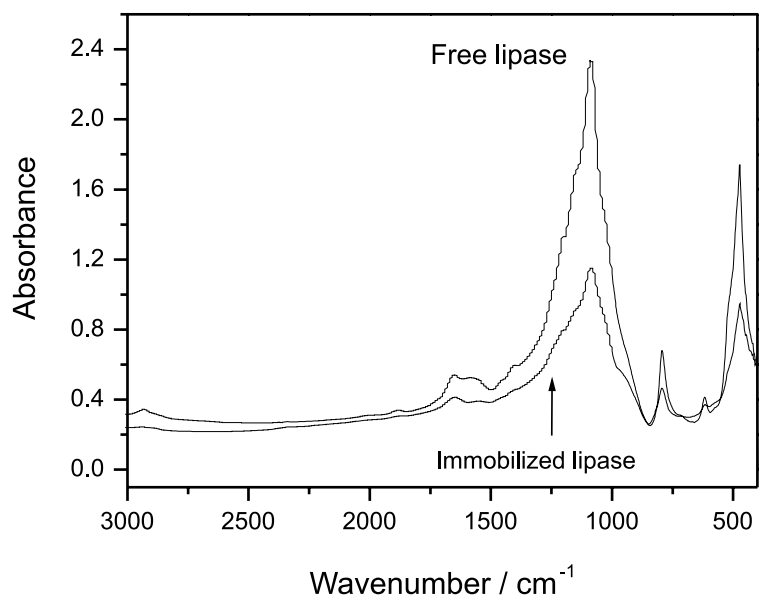

Figure 7. FTIR spectra for free and immobilized lipase.

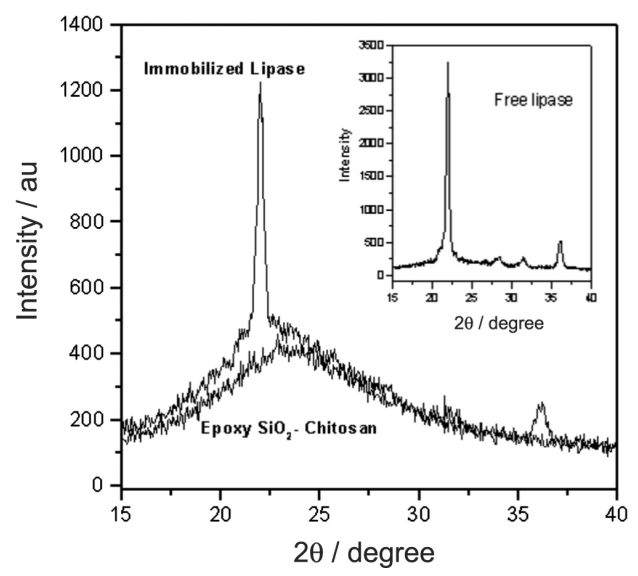

Figure 8. X-ray diffractograms for epoxy $\mathrm{SiO}_{2}$-chitosan and immobilized derivative. Inserted box shows diffractogram for free lipase. 


\section{Biochemical and kinetics properties of the immobilized derivative}

The influence of the variables $\mathrm{pH}$ and temperature on the hydrolytic activities for free and immobilized lipase was assessed by two level factor central composite rotatable design (CCRD) with three replications at the center point taking the hydrolytic activities as response variable. The experimental matrix and the results are shown in Table 1.

Table 1. Experimental design and results according to the central composite " $2^{2}+$ star"

\begin{tabular}{lcccc}
\hline Run & \multicolumn{2}{c}{ Variable } & \multicolumn{2}{c}{ Hydrolytic activity / $\left(\mathrm{U} \mathrm{g}^{-1}\right)$} \\
\cline { 2 - 5 } & $\mathrm{pH}$ & Temperature / $\left({ }^{\circ} \mathrm{C}\right)$ & $\begin{array}{c}\text { Free } \\
\text { Lipase }\end{array}$ & $\begin{array}{c}\text { Immobilized } \\
\text { lipase }\end{array}$ \\
\hline 1 & 6.5 & 40 & 13215 & 1177 \\
2 & 8.5 & 40 & 16593 & 1365 \\
3 & 6.5 & 60 & 15307 & 1984 \\
4 & 8.5 & 60 & 9361 & 1235 \\
5 & 7.5 & 50 & 32748 & 1489 \\
6 & 6.1 & 50 & 9801 & 1998 \\
7 & 8.9 & 50 & 14023 & 1507 \\
8 & 7.5 & 36 & 20291 & 1257 \\
9 & 7.5 & 64 & 20189 & 1356 \\
10 & 7.5 & 50 & 35181 & 1410 \\
11 & 7.5 & 50 & 34500 & 1301 \\
12 & 7.5 & 50 & 33381 & 1458 \\
\hline
\end{tabular}

For the free lipase, activity values were 9361 to $35181 \mathrm{U} \mathrm{g}^{-1}$ and immobilized lipase values varied from 1177 to $1997 \mathrm{U} \mathrm{g}^{-1}$. The highest values were attained at $\mathrm{pH} 7.5$ and temperature $50{ }^{\circ} \mathrm{C}$ (assay 10) for the free lipase and $\mathrm{pH} 6.1$ and temperature $50{ }^{\circ} \mathrm{C}$ (assay 6) for the immobilized lipase.

The individual effects and interaction of factors $(\mathrm{pH}$ and temperature) in hydrolytic activity for free and immobilized lipases were estimated with aid of Statistica 5.0. Table 2 displays the estimative of the effects of the variables, standard error and $p$-values.

Based on a 95\% confidence level, models and each term were tested to be significant using Fisher's statistical test for analysis of variance (ANOVA). Predict values for models indicated that the regression was significant at $95 \%$ confidence level without lack of fit ( $p>0.10)$. Results are described in Table 3 (free lipase) and Table 4 (immobilized derivative).

The models were checked by the determination coefficient and values $\left(R^{2}>0.9055\right)$ indicated that the sample variation of $90.55 \%$ for hydrolytic activities is attributed to the independent variables and less than $10 \%$ of the total variations are not explained by the model. Thus, the equations were considered adequate to describe hydrolytic activity as a function of study variables and were used to plot the response surfaces as shown in Figures $9 a$ and $9 b$.

The response surface for free lipase (Figure 9a) showed a top corresponding to a temperature of $50{ }^{\circ} \mathrm{C}$ and $\mathrm{pH}$ 7.5. For the immobilized lipase, saddle-shaped response surface was obtained (Figure 9b), within a maximum point corresponding to a temperature of $50{ }^{\circ} \mathrm{C}$ and $\mathrm{pH} 6.1$.

The shift of optimal $\mathrm{pH}$ for immobilized lipase has been reported for different lipase sources and support types. ${ }^{33,36}$ Generally, immobilized lipases on polycationic supports shift its optimum $\mathrm{pH}$ to the acidic range. Huang et al. ${ }^{37}$ reported that $\mathrm{pH}$ optimum for immobilized lipase from C. rugosa onto chitosan nanofibrous membrane shifted slightly from 7.7 to 7.5 when compared with the free one. In this study, a similar behavior was observed.

Under these optimal conditions, the kinetic parameters were determined for each lipase preparation. Figure 10 displays the curve profile for hydrolytic activities as a function of substrate concentration expressed in fatty acids molarity varying from 372 to $1860 \mathrm{mmol} \mathrm{L}^{-1}$. Results showed that both lipase preparations obeyed the Michaelis-Menten equation, indicating that in the studied range, no inhibition by the reaction product was detected.

Table 2. Estimated effects, standard errors and Student's $t$ test for the hydrolytic activity of free and immobilized lipase on epoxy $\mathrm{SiO}_{2}$-chitosan using the $2^{2}$ central composite " $2^{2}+$ star"

\begin{tabular}{|c|c|c|c|c|c|c|}
\hline \multirow[t]{2}{*}{ Variable } & \multicolumn{3}{|c|}{ Free lipase } & \multicolumn{3}{|c|}{ Immobilized lipase on $\mathrm{SiO}_{2}$-chitosan } \\
\hline & Effect & Standard Error & $\mathrm{p}$ & Effect & Standard Error & $\mathrm{p}$ \\
\hline Mean & 33953 & \pm 547 & $0.000^{*}$ & 1414 & \pm 41 & $0.000^{*}$ \\
\hline $\mathrm{X}_{1}$ (Linear) & 850 & \pm 773 & 0.352 & -314 & \pm 58 & $0.012 *$ \\
\hline $\mathrm{X}_{1}$ (Quadratic) & -23274 & \pm 865 & $0.000^{*}$ & 293 & \pm 65 & $0.020^{*}$ \\
\hline $\mathrm{X}_{2}$ (Linear) & -1321 & \pm 773 & 0.186 & 204 & \pm 58 & $0.039^{*}$ \\
\hline $\mathrm{X}_{2}($ Quadratic) & -14943 & \pm 865 & $0.000 *$ & -153 & \pm 65 & 0.101 \\
\hline $\mathrm{X}_{1} \mathrm{X}_{2}$ & -4663 & \pm 1093 & $0.024 *$ & -469 & \pm 82 & $0.011^{*}$ \\
\hline
\end{tabular}

*significant at $95 \%$ confidence level; $\mathrm{X}_{1}$ and $\mathrm{X}_{2}$ represent the variables $\mathrm{pH}$ and temperature, respectively. 
Table 3. Analysis of variance (ANOVA) for the model that represents the hydrolytic activity of the free lipase PS as a function of pH $\left(\mathrm{X}_{1}\right)$ and temperature $\left(\mathrm{X}_{2}\right)$

\begin{tabular}{lccccc}
\hline Source & $\begin{array}{c}\text { Sum of Squares } \\
\left(\times 10^{3}\right)\end{array}$ & $\begin{array}{c}\text { Degree of } \\
\text { Freedom }\end{array}$ & $\begin{array}{c}\text { Mean Square } \\
\left(\times 10^{3}\right)\end{array}$ & $\mathrm{F}$ & $\mathrm{p}$ \\
\hline $\mathrm{X}_{1}$ & 1446 & 1 & 1446 & 1209 & 0.352 \\
$\mathrm{X}_{1}{ }^{2}$ & 866326 & 1 & 866326 & 724645 & $0.000^{*}$ \\
$\mathrm{X}_{2}$ & 3491 & 1 & 3491 & 2919 & 0.186 \\
$\mathrm{X}_{2}{ }^{2}$ & 357117 & 1 & 357117 & 298715 & $0.000^{*}$ \\
$\mathrm{X}_{1} \mathrm{X}_{2}$ & 21739 & 1 & 21739 & $6.024^{*}$ \\
Lack of fit & 24251 & 3 & 8084 & 6.075 & \\
Pure Error & 3586 & 3 & 1196 & & \\
Total SS & 1097 & 11 & & & \\
\hline
\end{tabular}

*significant at $95 \%$ confidence level; $\mathrm{x}_{1}$ and $\mathrm{x}_{2}$ represent the variables $\mathrm{pH}$ and temperature, respectively.

Table 4. Analysis of variance (ANOVA) for the model that represents the hydrolytic activity of the immobilized lipase as a function of $\mathrm{pH}\left(\mathrm{X}_{1}\right)$ and temperature $\left(\mathrm{X}_{2}\right)$

\begin{tabular}{|c|c|c|c|c|c|}
\hline Source & $\begin{array}{l}\text { Sum of Squares } \\
\left(\times 10^{3}\right)\end{array}$ & $\begin{array}{l}\text { Degree of } \\
\text { Freedom }\end{array}$ & $\begin{array}{c}\text { Mean Square } \\
\left(\times 10^{3}\right)\end{array}$ & F & $\mathrm{p}$ \\
\hline $\mathrm{X}_{1}$ & 197384 & 1 & 197383 & 29079 & $0.012 *$ \\
\hline $\mathrm{X}_{1}^{2}$ & 137706 & 1 & 137706 & 20287 & $0.020 *$ \\
\hline $\mathrm{X}_{2}$ & 83351 & 1 & 83350 & 12279 & $0.039 *$ \\
\hline $\mathrm{X}_{2}^{2}$ & 37220 & 1 & 37219 & 5483 & 0.101 \\
\hline $\mathrm{X}_{1} \mathrm{X}_{2}$ & 219820 & 1 & 219820 & 32384 & $0.011^{*}$ \\
\hline Lack of fit & 54153 & 3 & 18051 & 2659 & 0.221 \\
\hline Pure Error & 20363 & 3 & 6787 & & \\
\hline Total SS & 787081 & 11 & & & \\
\hline
\end{tabular}

*significant at $95 \%$ confidence level; $\mathrm{X}_{1}$ and $\mathrm{X}_{2}$ represent the variables $\mathrm{pH}$ and temperature, respectively.
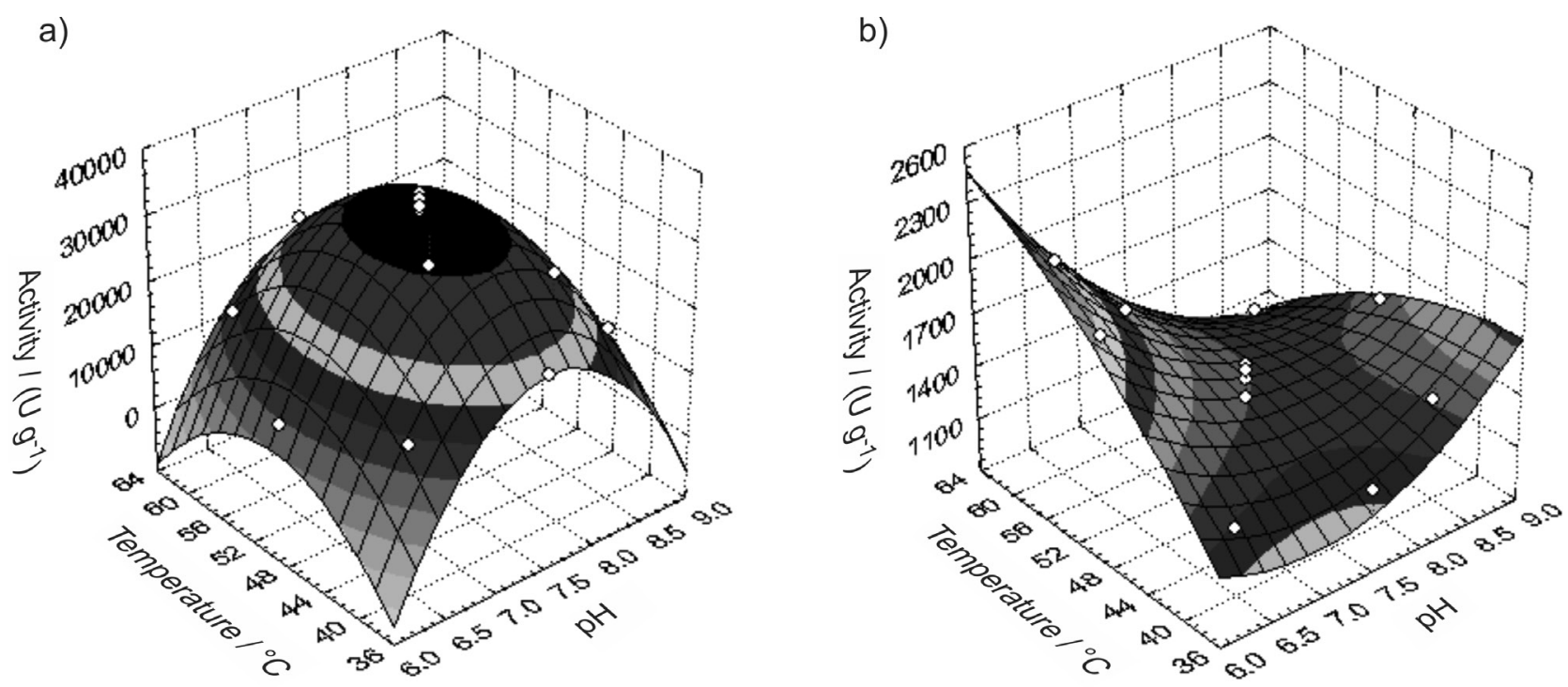

Figure 9. Surface responses for the hydrolytic activity of the Burkholderia cepacia lipase in the free form (a) and immobilized on epoxy $\mathrm{SiO}_{2}$-chitosan (b) as a function of the variables $\mathrm{pH}$ and temperature according to the fitted mathematical models.

The apparent value of $\mathrm{K}_{\mathrm{m}}$ for the immobilized lipase $\left(819 \mathrm{mmol} \mathrm{L}^{-1}\right)$ was almost three times higher than that for the native enzyme $\left(334 \mathrm{mmol} \mathrm{L}^{-1}\right)$ and the maximum reaction rate $\left(\mathrm{V}_{\text {max }}\right)$ were $16268 \mathrm{U} \mathrm{g}^{-1} \mu \mathrm{mol} \mathrm{g}{ }^{-1} \mathrm{~min}^{-1}$ and $1921 \mu \mathrm{mol} \mathrm{g}{ }^{-1} \mathrm{~min}^{-1}$ for the free and immobilized lipase samples, respectively. 


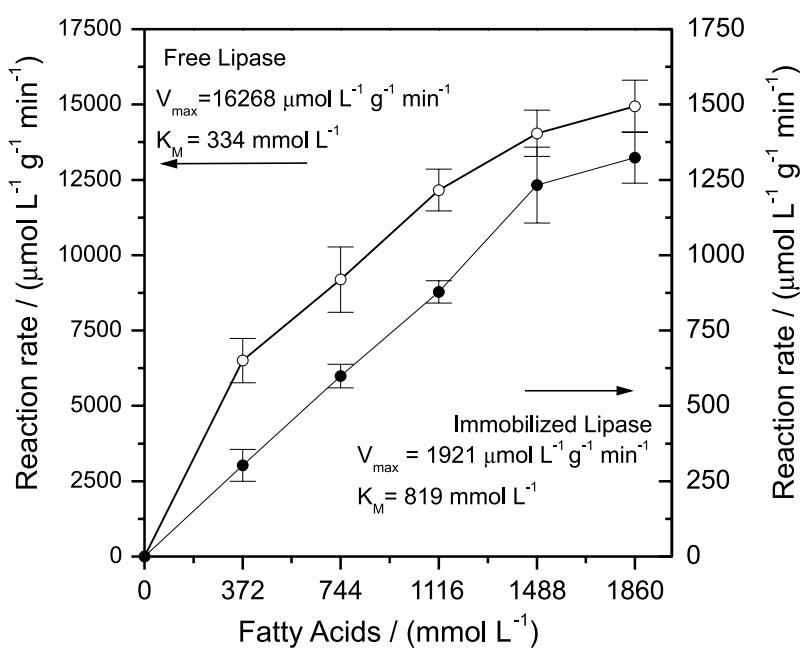

Figure 10. Hydrolytic activities for free and immobilized lipase on epoxy $\mathrm{SiO}_{2}$-chitosan as a function of the substrate concentration (expressed in total fatty acids content in olive oil/water emulsions).

The kinetic values $\left(\mathrm{K}_{\mathrm{m}}\right.$ and $\left.\mathrm{V}_{\max }\right)$ indicate a change in affinity of immobilized enzyme to substrate. Changes in the kinetic parameters are found to be dependent on the enzyme source, kind of support, immobilization method and enzyme-support interactions. ${ }^{38} \mathrm{In}$ this work, $\mathrm{K}_{\mathrm{m}}$ value for the immobilized lipase is higher than that of free lipase, which means the loss of affinity of lipase from substrate. A similar result involving increase in the $\mathrm{K}_{\mathrm{m}}$ value of lipase after immobilization has been reported in the literature. ${ }^{39}$ This increment after immobilization might either be due to structural changes in the enzyme induced by the applied immobilization procedure, or due to the use of epichlorohydrin as the activating agent. Moreover, the interactions of enzyme-support and diffusion resistance of carrier can be promoted by the lower accessibility of the substrate to the active sites of the immobilized enzyme.

\section{Stability tests}

Experiments were performed to determine the thermal deactivation constants $\left(\mathrm{k}_{\mathrm{d}}\right)$ and the half-life time for free and immobilized lipase under thermal effect at $60{ }^{\circ} \mathrm{C}$ and results are displayed in Figure 11. Patterns of heat stability indicated that the immobilization process tends to stabilize the enzyme. In this case, half-life time $\left(t_{1 / 2}\right)$ of the enzyme is shown to be inversely proportional to the rate of denaturation $\left(\mathrm{k}_{\mathrm{d}}\right)$. The half-life time $\left(\mathrm{t}_{1 / 2}\right)$ is the time which takes for the activity to reduce to a half of the original activity.

Under these conditions, the immobilized lipase exhibited higher stability against heat than the soluble form. While the free enzyme was practically inactivated after $1 \mathrm{~h}$ incubation at $60^{\circ} \mathrm{C}$, the immobilized lipase preserved about $40 \%$ of its original activity. Inactivation constants $\left(\mathrm{k}_{\mathrm{d}}\right)$ and half-life $\left(\mathrm{t}_{1 / 2}\right)$ for both free and immobilized lipases were calculated, respectively as $\mathrm{k}_{\mathrm{d}}=9.6 \mathrm{~h}^{-1}\left(\mathrm{t}_{1 / 2=} 0.07 \mathrm{~h}\right)$ and $\mathrm{k}_{\mathrm{d}}=0.33 \mathrm{~h}^{-1}\left(\mathrm{t}_{1 / 2}=2.1 \mathrm{~h}\right)$ indicating a raise of thermal stability near 30 fold when compared to free enzyme. Thermal stability upon immobilization is the result of molecular rigidity and the creation of a protected microenvironment.

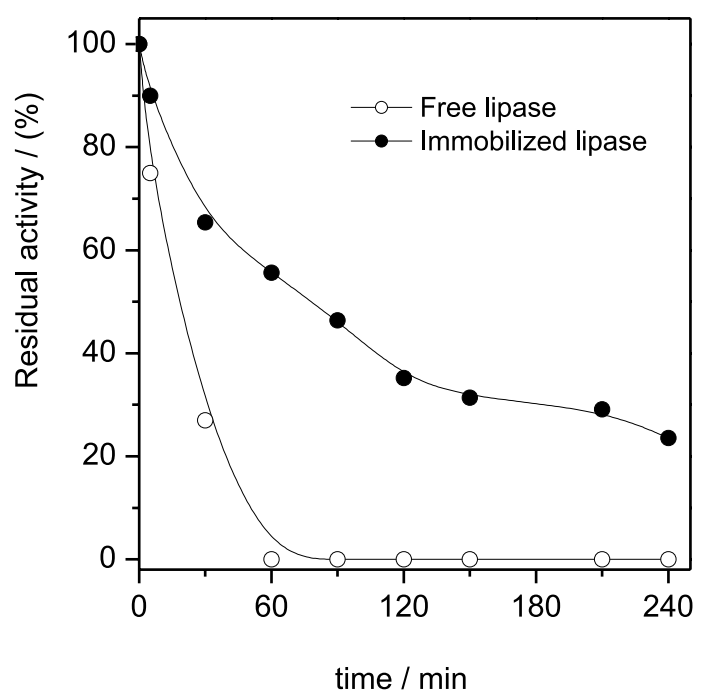

Figure 11. Thermal inactivation for free lipase (o) and epoxy $\mathrm{SiO}_{2}$-chitosan immobilized lipase $(\bullet)$. Experiments were carried out in $0.1 \mathrm{~mol} \mathrm{~L}^{-1}$ phosphate buffer $\mathrm{pH} 6.5$ at $60^{\circ} \mathrm{C}$.

These results were also confirmed by running TG analysis which also allows determining the temperature range at which a heated sample undergoes a major conformational change by means of monitoring the thermal weight change profile as well as parameters for thermal stability of support and free and immobilized lipase. The results of such analysis are shown in Table 5.

The free lipase shows two peaks in mass change, the first at $127^{\circ} \mathrm{C}$ (loss of water) and the second at $382{ }^{\circ} \mathrm{C}$ attributed to the decomposition of stabilizing agents present in the lipase preparation. ${ }^{40}$ On the other hand, the immobilized lipase shows an increase in the temperature of the first stage of decomposition $\left(174^{\circ} \mathrm{C}\right)$, attributed to the covalent bond of the biocatalyst on the hybrid matrix. The discrete increase in the temperature of the second stage $\left(397^{\circ} \mathrm{C}\right)$ took place by the additional cross linking degree after the activation step. These results indicate that upon immobilization, the thermal profile for the lipase derivative shifted towards higher temperatures because of a strong interaction between enzyme and hybrid matrix, which enhanced the conformational stability of the native form.

To better illustrate the catalytic properties observed for the Burkholderia cepacia immobilized onto 
Table 5.Thermogravimety data for support and immobilized derivative

\begin{tabular}{lccc}
\hline Sample & Step & $\begin{array}{c}\text { Temperature / } \\
\left({ }^{\circ} \mathrm{C}\right)\end{array}$ & $\begin{array}{c}\text { Mass loss / } \\
(\%)\end{array}$ \\
\hline Epoxy $\mathrm{SiO}_{2}$-chitosan & $1^{\text {st }}$ & 162 & 10 \\
& $2^{\text {nd }}$ & 537 & 20 \\
Free lipase & $1^{\text {st }}$ & 127 & 2 \\
& $2^{\text {nd }}$ & 382 & 15 \\
Immobilized lipase & $3^{\text {rd }}$ & 546 & 22 \\
& $1^{\text {st }}$ & 174 & 14 \\
& $2^{\text {nd }}$ & 397 & 21 \\
& $3^{\text {rd }}$ & 517 & 24 \\
\hline
\end{tabular}

Table 6. Biochemical and kinetic properties for the free and immobilized lipase $\mathrm{PS}$ on $\mathrm{SiO}_{2}$-chitosan

\begin{tabular}{|c|c|c|}
\hline Parameter & Free Lipase & $\begin{array}{l}\text { Immobilized } \\
\text { Lipase }\end{array}$ \\
\hline Optimum pH & 7.5 & 6.1 \\
\hline Optimum Temperature / $\left({ }^{\circ} \mathrm{C}\right)$ & 50 & 50 \\
\hline Half-life time $\left(\mathrm{t}_{1 / 2}\right)$ at $60^{\circ} \mathrm{C} / \mathrm{h}$ & 0.07 & 2.1 \\
\hline $\begin{array}{ll}\text { Kinetic Parameters } & \mathrm{K}_{\mathrm{m}} /\left(\mathrm{mmol} \mathrm{L}^{-1}\right) \\
& \mathrm{V}_{\max } /\left(\mathrm{U} \mathrm{g}^{-1}\right)\end{array}$ & $\begin{array}{c}334 \\
16267\end{array}$ & $\begin{array}{c}819 \\
1921\end{array}$ \\
\hline
\end{tabular}

epoxy- $\mathrm{SiO}_{2}$-chitosan, the biochemical and kinetic properties of free and immobilized lipase are summarized in Table 6.

\section{Conclusions}

Epoxy $\mathrm{SiO}_{2}$-chitosan proved to be an attractive and efficient matrix to immobilize lipase due to its physical and chemical properties. The use of techniques such as $\mathrm{X}$-ray diffraction and FTIR confirmed incorporation of the enzyme onto the support matrix. Experimental design data showed the significant influence of $\mathrm{pH}$ and temperature in hydrolytic activity of free and immobilized lipase. Values of $\mathrm{K}_{\mathrm{m}}$ found for both lipase preparations indicated that immobilization process reduced the affinity of enzymesubstrate; however the $\mathrm{k}_{\mathrm{d}}$ value indicated an increase of thermal stability of lipase. These results showed the potential of the epoxy $\mathrm{SiO}_{2}$-chitosan matrix to immobilize lipases, particularly lipase PS. Moreover easiness of support synthesis and immobilization procedure, justify the importance of the evaluation of morphological and mechanical properties to obtain suitable carriers.

\section{Acknowledgments}

The authors are grateful for the financial support provided by FAPESP (Fundação de Amparo à Pesquisa do Estado de São Paulo) and CNPq (Conselho Nacional de Desenvolvimento Científico e Tecnológico), Brazil.

\section{References}

1. Guisan, J. M. In Immobilization of Enzyme and Cells, Guisan, J. M., ed.; $2^{\text {nd }}$ ed.; Humana Press: Totowa, 2006, ch. 1.

2. Christensen, M. W.; Andersenb, L.; Husumb, T. L.; Kirkb, O.; Eur. J. Lipid Sci. Technol. 2003, 105, 318.

3. Luckarift, H. R.; J. Liq. Chromatogr. Relat. Technol. 2008, 31, 1568.

4. Mateo, C.; Palomo, J. M.; Fernandez-Lorente, G.; Guisan, J. M.; Fernandez-Lafuente, R.; Enzyme Microb. Technol. 2007, 40, 1451

5. Bornscheuer, U. T.; Kazlauskas, R. J.; Hydrolases in Organic Synthesis: Regio- and Stereoselective Biotransformations, $2^{\text {nd }}$ ed.; Wiley-VCH: Weinheim, 2005, ch 5.

6. de Castro, H. F.; Zanin, G. M.; de Moraes, F. F.; Sá-Pereira, P. In Enzimas em Biotecnologia-Produção, Aplicações e Mercado; Bon, E. P. S.; Ferrara, M. A.; Corvo, M. L., eds.; Interciência: Rio de Janeiro, Brasil, 2008, ch. 6.

7. Zhou, Z.; Ruan, J.; Zou, J.; Zhou, Z.; J. Univ. Sci. Technol. Beijing 2008, 15, 290.

8. Nocun, M.; Cholewa-Kowalska, K.; Laczka, M. S.; J. Mol. Struct. 2009, 938, 24.

9. Addamo, M.; Augugliaro, V.; Paola, A. D.; Garcia-Lopez, E.; Loddo, V.; Marci, G.; Thin Solid Films 2008, 516, 3802.

10. Pappas, G. S.; Liatsi, P.; Kartsonakis, I. A.; Danilidis, I.; Kordas, G.; J. Non-Cryst. Solids 2008, 354, 755.

11. Seckin, T.; Koytepe, S.; Ibrahim, A. H.; Mater. Chem. Phys. 2008, 112, 1040.

12. Xie, K.; Zhang, Y.; Yu, Y.; Carbohydr. Polym. 2009, 77, 858.

13. Shchipunov, Y. A.; J. Colloid Interface Sci. 2003, $268,68$.

14. Santos, J. C.; Paula, A. V.; Nunes, G. F. M.; de Castro, H. F.; J. Mol. Catal. B: Enzym. 2008, 52, 49.

15. Zou, Y.; Xiang, C.; Sun, L.-X.; Xu, F.; Biosens. Bioelectron. 2008, 23, 1010.

16. Paula, A. V.; Moreira, A. B. R.; Braga, L. P.; de Castro, H. F.; Bruno, L. M.; Quim. Nova 2008, 31, 35.

17. Kataoka, K.; Nagao, Y.; Nukui, T.; Akiyama, I.; Tsuru, K.; Hayakawa, S.; Biomaterials 2005, 26, 2509.

18. Li, J.; Srinivasan, S.; He, G. N.; Kang, J. Y.; Wu, S. T.; Ponce, F. A.; J. Cryst. Growth 2008, 310, 599.

19. Zhou, Z.; Cui, L.; Zhang, Y.; Yin, N.; Eur. Polym. J. 2008, 44, 3057.

20. Krishnapriya, K. R.; Kandaswamy, M.; Carbohydr. Res. 2009, $344,1632$.

21. Luo, X. -L.; Xu, J. -J.; Zhang, Q.; Yang, G. -J.; Chen, H. -Y.; Biosens. Bioelectron. 2005, 21, 190.

22. Freitas, L.; Da Rós, P. C. M.; Santos, J. C.; de Castro, H. F.; Process Biochem. 2009, 44, 1068.

23. Moreira, A. B. R.; Perez, V. H.; Zanin, G. M.; de Castro, H. F.; Energy Fuels 2007, 21, 3689.

24. Soares, C. M. F.; de Castro, H. F.; Moraes, F. F.; Zanin, G. M.; Appl. Biochem. Biotechnol. 1999, 77, 745. 
25. Rashidova, S. S.; Shakarova, D. S.; Ruzimuradov, O. N.; Satubaldieva, D. T.; Zalyalieva, S. V.; Shpigun, O. A.; Varlamov, V. P.; Kabulov, B. D.; J. Chromatogr., B: Anal. Technol. Biomed. Life Sci. 2004, 800, 49.

26. Smitha, S.; Shajesh, P.; Mukundan, P.; Warrier, K. G. K.; J. Mater. Res. 2008, 23, 2053.

27. Al-Sagheer, F.; Muslim, S.; J. Nanomat. 2010, 2010, 7. (doi:10.1155/2010/490679).

28. Stuart, B.; George, W. O.; Mcintyre, P. S.; Modern Infrared Spectroscopy, John Wiley \& Sons: England, 1996.

29. Ogawa, K.; Yui, T.; Okuyama, K.; Int. J. Biol. Macromol. 2004, 34,1 .

30. Witoon, T.; Chareonpanich, M.; Limtrakul, J.; J. Sol-Gel Sci. Technol. 2009, 51, 146.

31. Neto, C. G. T.; Giacometti, J. A.; Job, A. E.; Ferreira, F. C.; Fonseca, J. L. C.; Pereira, M. R.; Carbohydr. Polym. 2005, 62, 97.

32. Berger, J.; Reist, M.; Mayer, J. M.; Felt, O.; Peppas, N. A.; Gurny, R.; Eur. J. Pharm. Biopharm. 2004, 57, 19.
33. Krajewska, B.; Enzyme Microb. Technol. 2004, 35, 126.

34. Bayramoglu, G.; Meltem, Y.; Arica, M. Y.; Bioprocess Biosyst. Eng. 2010, 33, 439.

35. Soares, C. M. F.; Santos, O. A.; Olivo, J. E.; de Castro, H. F.; Moraes, F. F.; Zanin, G. M.; J. Mol. Catal. B: Enzym. 2004, 29, 69.

36. Balcão, V. M.; Paiva, A. L.; Malcata, F. X.; Enzyme Microb. Technol. 1996, 18, 392.

37. Huang, X. J.; Ge, D.; Xu, Z. K.; Eur. Polym. J. 2007, 43, 3710.

38. Villeneuve, P.; Muderhwa, J. M.; Graille, J.; Haas, M. J.; J. Mol. Catal. B: Enzym. 2000, 9, 113.

39. Chiou, S.; Wu, W.; Biomaterials 2004, 25, 197.

40. De María, P. D.; Sánchez-Montero, J. M.; Alcántara, A. R.; Valero, F.; Sinisterra, J. V.; Biotechnol. Lett. 2005, 27, 499.

Submitted: November 27, 2010

Published online: March 31, 2011

FAPESP has sponsored the publication of this article. 